\title{
Analysis of Overall and Pure Technical Efficiency of Tourism in Europe
}

\section{Vesna Prorok ${ }^{a}$, Neven Šerićb, Ivan Peronjac}

The aim of this paper is to assess the overall and pure technical efficiency of tourism in European countries in 2017 using the output-oriented Charnes, Cooper and Rhodes (1978, 1979), and Banker, Charnes and Cooper (1984) data envelopment analysis methodology. The countries were divided into two groups: European Union countries and non-European counties. We identified two input and two output variables for each group. Input variables were identified using the principal component analysis method, starting from fourteen pillars that measure the performance of countries in the field of travel and tourism, and are published in the regular reports of the World Economic Forum. Then, two output variables were defined (the total (direct and indirect) contribution of travel and tourism to gross domestic product, and the direct contribution of tourism to employment growth rate), to determine the relative efficiency of decision-making units within the formed homogeneous groups of countries, among which the group of Western Balkan countries was singled out. This analysis enabled us, based on relatively scarce potential, to propose guidelines for a tourism development strategy for the entire Western Balkans region.

\author{
a. University of East Sarajevo, Faculty of Economics, Pale, Bosnia and Herzegovina \\ e-mail: vesna.prorok@ekofis.ues.rs.ba \\ b. University of Split, Faculty of Economics, Business and Tourism, Split, Croatia \\ e-mail: nevenseric@efst.hr \\ c. University of Split, Faculty of Maritime Studies, Split, Croatia \\ e-mail: iperonja@pfst.hr \\ doi: 10.7225/toms.v08.n02.07 \\ This work is licensed under (cc) BY
}

\author{
KEY WORDS \\ $\sim$ Tourism \\ $\sim$ Technical efficiency \\ $\sim$ DEA \\ $\sim$ Methodology
}

\section{INTRODUCTION}

Globally, tourism is one of the most dynamic and fastest growing economic activities, which has, unlike other economic activities, been characterized by continuous growth and development, especially over the last two decades. Although tourism is primarily perceived as an opportunity for accelerated economic development in many countries, it simultaneously requires economic policy holders to face a range of challenges and show willingness to perform complex tasks to create the conditions for cooperation between a large number of business entities, both at the national and international level. In addition to numerous economic and social opportunities, the development of tourism contributes to greater international openness and geographic connectivity of the country, resulting in increased income and the development of cheap air transport as an accompanying and necessary element of successful development.

As a matter of fact, strong development of tourism increases opportunities for employment and raises income levels, improves living standards and contributes to the elimination of a number of financial and institutional barriers. Unsurprisingly, low- and middle income level countries are particularly keen on its development. Tourism is seemingly the most realistic development concept, since the inputs necessary for competitive positioning at international level are not insurmountable, as is the 
case with technologically-intensive branches. Moreover, tourism is a labor-intensive branch of economy with high added value, its development undoubtedly opens new jobs and is characterized by growing employees' incomes, confirming that it is a branch that does not build its competitiveness on cheap labor.

If we analyze the tourism offer of a country or a region, it should be emphasized that it is most commonly based on natural and cultural-historical components that are most often present in underdeveloped and passive areas. Today, the competitiveness of such resources is largely dependent on innovative ideas and marketing strategies aimed at attracting more tourists in order to ensure a balanced and unified regional development (JakšićStojanović and Šerić, 2018). From the point of view of demand, the prospects and the potential for expansion are relatively unlimited, giving even underdeveloped economies an opportunity to identify their potentials relying on pre-existing inputs and reap the benefits of tourism with minimum investment.

By definition, the efficiency of tourism industry is the extent to which a particular region exploits its tourism resources (Luo and Qian, 2017). Starting from the definition of tourism efficiency, the purpose of this research was to measure and analyze the relevance of efficiency of investment into tourism in European countries, with a particular focus on the Western Balkan countries. Our aim is to point out the problems and sources of inefficiency of tourism in Western Balkan countries and, accordingly, propose guidelines for a development strategy that will increase the relevance of tourism in these countries. Proposal guidelines will be based on an empirical study of best practices of various forms of year-round tourist offer at the global level. In line with innovative trends in tourism, the proposed efficiency improvement measures will be based on the development of certain specialized tourism products.

\section{LITERATURE OVERVIEW}

Previous studies in this area mainly focused on the assessment of tourism efficiency of provinces, regions, countries or even groups of countries, and were carried out in order to define tourism development strategies which would provide guidelines for easier and more efficient placement of existing or new tourism services to potential tourists.

Botti, Peypoch, Robinot and Solonandrasana (2009) examined the tourism efficiency of 22 regions in France using the output-oriented data envelopment analysis (DEA) methodology. The analysis was based on the number of tourists as the output variable and on 6 input variables: number of hotels, camps, parks, monuments, museums and miles of available beaches. Technical efficiency was achieved in 10 regions, which can serve as examples of good practice and benchmarks for increasing efficiency in the remaining regions. Similar analysis was performed by Barros, Botti, Peypoch, Pobinot, Solonandrasan and Assaf (2011). The analysis also included 22 French regions in the period 2003- 2007 and was based on the application of the two-stage DEA method. In the first stage, efficiency coefficients for each region were estimated based on two input variables (accommodation capacities and number of tourist arrivals) and one output variable (number of overnight stays). In the second phase, using regression analysis with the inclusion of variables representing tourist attractions (monuments, museums, parks, beaches, ski resorts and natural parks), the authors came to the conclusion that the efficiency is most dependent on sea exit and coast tidiness. The proposed development strategy for regions which do not meet these requirements is to increase the number of theme parks, monuments, ski resorts and nature parks. The authors believe that the expansion of the tourist offer and the number of tourist attractions increase the efficiency of the least developed tourist regions. Encouraged by the importance of tourism for a country's economy and the growth of tourism market competitiveness due to the transition from mass tourism to the specific needs of tourists, Cracolici, Nijkamp and Rietveld (2008) analyzed the technical efficiency of destinations from 103 regions in Italy in 2001. Competitiveness in terms of technical efficiency was examined by using the parametric stochastic frontier analysis (SFA) and the nonparametric DEA method. The SFA method showed variability in terms of effectiveness across the region, indicating that regions with artistic and cultural attractions were better rated than mountainous or coastal regions. Some lower efficiency scores were obtained by using the DEA method, due to the insufficient homogeneity of observed regions. Gucci and Rizzo (2013) applied two-stage DEA method to establish the extent to which UNESCO nominations determined the efficiency of tourist destinations and the flow of tourist travels in Italian regions in 1995-2010. The results showed that although UNESCO nominations had a negative short-term impact on the efficiency of tourist destinations, their long-term impact was not statistically significant. This is because tourists value cultural content and natural attractions when choosing a destination, which UNESCO-nominated destinations mostly miss. In order for UNESCO nominations to have a positive impact on efficiency, it is essential that such sites are made accessible to tourists, secured with material and immaterial infrastructure and enriched with cultural events. Encouraged by such analyses, many authors have tried to evaluate the tourism efficiency of the less developed European countries in order to develop a strategy for increasing their competitiveness, and thus the exploitation of both natural and cultural-historical components that are frequently found in underdeveloped areas. One such study was conducted by Tom (2014), who examined the efficiency of 8 regions in Romania in 2012, using the input-oriented DEA method with 4 input and 5 output variables. The analysis examined the efficiency of 5 regions. One region was technically inefficient due to the supply of tourist capacities surpassing demand, while 2 were inefficient 
because the tourist demand for accommodation facilities grew faster than supply. In the Asian market similar analysis was performed by Bi, Lou and Liang (2014). The analysis evaluated the efficiency of 31 provinces in China through two stages defined as the capacity building stage and the benefit creating stage. In the first stage there were 19, and in the second 22 efficient provinces, but according to the overall estimate, only 6 provinces had efficiency scores equal to one (Beijing, Inner Mongolia, Shanghai, Henan, Qinghai and Ningxai), while the worst-rated province was Hebei with an efficiency score of 0.3890 .

Of the studies that included a group of countries from one or more regions, we will mention only those analyzing the efficiency of European countries, given that such analyses are the closest to the research that will be carried out in this paper. Cvetkoska and Barišić (2014) measured the efficiency of 15 European countries (Austria, Bosnia and Herzegovina, Bulgaria, Croatia, Cyprus, Czech Republic, France, Greece, Italy, Macedonia, Montenegro, Portugal, Serbia, Slovenia and Spain) in 2004-2013 using Window-DEA analysis method. By selecting two input and two output variables, with the formation of 6 windows covering 5-year periods, the highest efficiency scores were achieved in 2004, and the lowest in 2011. According to results, no country achieved full efficiency in all years and in all windows, but 10 out of 15 countries had an efficiency coefficient of over 0.95 . Montenegro was identified as the country with the lowest efficiency, while four countries with the highest scores were: Italy, Cyprus, France and Spain. Kosmaczewska (2014) analyzed 27 EU member countries in 2007-2009. The results have shown that wealthier countries have achieved a higher level of technical efficiency, while developing countries have reached a higher level of scale efficiency. This can be explained, inter alia, by the fact that tourism development largely depends on investments, which are more easily available in wealthier countries. However, opportunities for efficiency improvement in wealthier countries are ever decreasing, given that the tourist services that these countries offer are already at an extremely high level of development. At the moment, this does not leave much room for investors, who have been increasingly turning to developing countries in search of opportunities to increase their capital. Developing countries or groups of developing countries which constitute one region, first of all, should recognize their competitive advantages over other countries and accordingly develop strategies that will attract investors and potential tourists. In a comprehensive list of research results, it is interesting to note the study of authors Martín, Mendoza and Román (2015), who have created a unique competitiveness index at the global level and ranked 139 countries using the DEA method, by analyzing their geographic position and national income. Describing the differences in the characteristics of the best and worst-rated countries, and their geographic areas, this paper has made a significant contribution to the mapping of profiles that in the near future can be used by economic policy-makers to form strategies that will maximize their use and increase their tourism potential.

All efforts in literature so far enable future authors to use the DEA method in their research to a greater extent, which will, in combination with other parametric and nonparametric methods, provide relevant assessments of tourism efficiency (Šerić and Ljubica, 2018). This study as well will focus on the evaluation of efficiency of tourism in European countries, based on which the Western Balkan countries will be positioned in terms of efficiency, with the aim of proposing guidelines for a tourism strategy oriented on the expansion of the tourist offer through innovative forms of tourism and the development of specialized tourist products (Jakšić-Stojanović and Šerić, 2018).

\section{METHODOLOGY}

\subsection{Charnes, Cooper and Rhodes (CCR) DEA Model}

The non-parametric DEA method was proposed by Charnes, Cooper and Rhodes (1978), to define the relative measure of efficiency of the decision-making units when a large number of output and input variables are present. The relative measure of efficiency using the DEA method is determined by the ratio of weighted output values and weighted input values for each individual observed unit. The observed units are compared with each other by the formation of a linear programming model. The efficiency frontier is composed of observed units with the best business practices, while the efficiency of all other units is determined on the basis of the distance from the defined efficiency frontier. Units at the frontier are considered relatively efficient, while those out of the frontier are relatively inefficient. A set of efficient units is viewed as a reference point for proposing improvements to relatively inefficient units (Prorok and Bošnjak, 2018).

Suppose we have ${ }_{n}$ decision-making units (DMUs) and that each of the units $D M U_{j},(j=, 2, \ldots, n)$ produces $s$ outputs of the same type and of different values, $y_{r j}(r=1,2, \ldots, s)$, using different $m$ input values of the same type, $x_{i j}(i=1,2, \ldots, m)$.

The CCR model is designed to obtain for each $k$ - the decision-making unit $D M U_{k}(\mathrm{k}=1,2, \ldots, \mathrm{n})$ the optimization task of the relationship between the virtual output and the virtual input, in order to determine the weight coefficients for the output and input variables to which the value of the relationship will be maximized:

$$
(\max ) h_{k}=\frac{\sum_{r=1}^{s} u_{r} y_{r k}}{\sum_{i=1}^{m} v_{i} x_{i k}}
$$


with the following constraints:

$$
\frac{\sum_{r=1}^{s} u_{r} y_{r j}}{\sum_{i=1}^{m} v_{i} x_{i j}} \leq 1, j=1,2, \ldots, n
$$

$u_{r} \geq 0, \quad r=1,2, \ldots, s$

$v_{i} \geq 0, \quad i=1,2, \ldots, m$

where: $h_{k}$ - the relative efficiency of the $k$-th decision-making unit; $n$ - the number of decision-making units; $m$ - the number of inputs; $s$ - the number of outputs; $v_{i}$ - weight coefficients for input $i ; u_{r}$ - weight coefficient for output $r ; x_{i j}$ - the amount of input $i$ for the $j$-th decision-making unit, $\left(D M U_{j}\right) ; y_{j r}$ - the amount of output $r$ for the $j$-th decision-making unit, $\left(D M U_{j}\right)$.

\subsection{Banker, Charnes and Cooper (BCC) DEA Model}

The presented CCR model assumes that the observed units achieve constant returns to scale, i.e. the increase in the value of the engaged inputs by a certain percentage results in the same or approximately the same percentage of output increase. For this reason, the efficiency frontier formed on the basis of the CCR model has the shape of a convex cone.

All observed units positioned at the frontier of efficiency are considered to have full overall technical efficiency that includes both pure technical efficiency and the efficiency of scale. Baker, Charnes and Cooper (BCC) proposed the measurement of pure efficiency by extended basic CCR DEA model in 1984.

BCC model provides an assessment of pure efficiency, excluding the effect of the business scale by comparing the observed units exclusively to other units of similar size.

The mathematical formulation of the BCC model, unlike the CCR model represented by the expressions (3.1)-(3.4), includes an additional variable $u^{*}$. The decision on whether the additional variable will be included in the numerator or the denominator depends on whether the general form of the BCC model is transformed into a linear programming model with output or input orientation. The purpose of introduction of an additional variable is to set up a constraint on returns to scale and to ensure the formation of the reference set on the basis of a convex combination of decision-making units (Prorok and Bošnjak, 2018).

The general formulation of the BCC model is given by:

$$
(\max ) h_{k}=\frac{\sum_{r=1}^{s} u_{r} y_{r k}-u^{*}}{\sum_{i=1}^{m} v_{i} x_{i k}}
$$

With the following constraints:

$$
\begin{aligned}
& \frac{\sum_{r=1}^{s} u_{r} y_{r j}-u^{*}}{\sum_{i=1}^{m} v_{i} x_{i j}} \leq 1, j=1,2, \ldots, n \\
& u_{r} \geq \varepsilon, \quad r=1,2, \ldots, s
\end{aligned}
$$

$v_{i} \geq \varepsilon, \quad i=1,2, \ldots, m$

\subsection{Window DEA Analysis}

Window DEA analysis is a specific form of the DEA method that allows the changes in the efficiency of the observed units to be observed over a given period of time. The method involves defining windows covering multiple time frames, where each observed unit is treated as a separate observed unit at different times. This allows the comparison of the efficiency of not only one unit over time, but also its comparison with other units that are covered by the defined window.

The Window DEA analysis allows us to increase the number of observed decision-making units and to include the time dimension of the data by analysis. However, the main disadvantage of this method is that, by moving windows, certain time units are tested several times, while time frames corresponding to the first and last periods are tested only once, because they are only covered by the first and last window, respectively.

The Window DEA analysis will be used in this paper to test the overall and pure technical efficiency of insurance companies 
in Bosnia and Herzegovina and rank the most efficient decisionmaking units based on average efficiency estimates, both through windows and time periods. (Prorok and Bošnjak, 2018)

\section{IDENTIFICATION OF INPUT AND OUTPUT VARIABLES FOR THE EVALUATION OF EFFICIENCY OF TOURISM IN EUROPEAN COUNTRIES}

\subsection{Identification of Input Variables}

Although the DEA method is an excellent optimization technique for the assessment of tourism efficiency, certain limitations still exist. Limitations occur when the number of input and output variables is relatively high compared to the number of observed units. One of the ways to overcome this limitation might be to introduce only those variables (inputs and outputs) in the model which are the basic components of the production process. In this way, not only are the outcomes of the DEA method not affected, but it becomes even more effective.

In our evaluation of tourism efficiency in European countries, we tried to eliminate the shortcomings of the DEA by dividing countries into relatively homogeneous groups, depending on the resemblance of their available tourist resources, and adjusting the number of the defined input and output variables to the number of observed units. Key input variables were identified using the principal component analysis method, starting with the 14 pillars for the measurement of the performance of countries in the field of travel and tourism, which are published in the regular reports of the World Economic Forum (WEF).

In the 2013 report, the pillars were divided into three categories: Travel \& Tourism (T\&T) regulatory framework, T\&T business environment and infrastructure, and T\&T human cultural, and natural resources. However, as of 2015, the pillars have been divided into four categories: Enabling Environment, T\&T Policy and Enabling Conditions, Infrastructure, and Natural and Cultural Resources. The index of travel and tourism competitiveness is formed on the basis of the aforementioned categories and measures the performance of countries in the field of travel and tourism.

Given that first the countries and then tourist regions differ by the degree of tourism competitiveness achieved, it can be assumed that not all factors will have the same impact on the tourist performance of these countries. Therefore, the aim was to identify the main components that contributed to the competitiveness of tourism in European countries in 2017. We divided the countries into two groups: the EU member countries (28 countries) and countries outside the European Union (14 countries)
Two principal components were identified in both groups. In EU member countries, we noted that all variables with the highest factor load, which make up the first component, had positive signs, namely: 1) Business Environment, 2) Human resources and labor market, 3) Information and communication technology (ICT) Readiness, 4) International openness, 5) Environmental Sustainability, 6) Ground and port infrastructure; while the second component consists of variables: 1) Prioritization travel and tourism, 2) Price competitiveness, 4) Air transport infrastructure, 5) Tourist service infrastructure, 6) Natural resources, 7) Cultural resources and business travel, of which only the Price competitiveness variable had negative, while other variables had positive factor load. This suggests that if a given country is rated positively as a tourist destination for one attribute within the component that it determines, it will probably be highly rated by other attributes with the same sign within that component. On the other hand, countries that have highly rated attributes with a positive sign are likely to have some poorly rated attributes with a negative sign. Specifically, in our case, countries from the EU 28 , belonging to a group in which tourism is dependent on the second component, are likely to have poor ratings in terms of price competitiveness, if they have highly rated other variables that are mainly related to air transport, tourist infrastructure, and natural and cultural resources.

A similar structure of components was also noted in non-EU countries. The first component consists of the following group of variables: 1) Business Environment, 2) Safety and security, 3) Human resources and labor market, 4) ICT Readiness, 5) Prioritization travel and tourism, 6) International openness, 7) Price competitiveness, 8) Environmental Sustainability, 9) Ground and port infrastructure; 10) Tourist service infrastructure; while the second component consists of three variables, namely: 1) Air transport infrastructure, 2) Natural resources, 3) Cultural resources and business travel.

The identified main components were used as input variables in the assessment of tourism efficiency.

Having identified the main components, we conducted cluster analysis to group the countries into appropriate clusters according to the similarity of the tourism resources available to them. Hierarchical cluster analysis and k-means cluster analysis were used to determine the number of clusters and place the countries into the corresponding cluster. The analysis classified EU member states into 4 groups, and non-EU countries into three groups. Based on the ANOVA analysis, we confirmed that the clusters thus formed, within both observed groups of countries, were statistically significant.

The following table presents the results of cluster analysis, and defines positively and negatively profiled components for each cluster individually. 
Table 1.

Countries grouped by clusters - for EU and non-EU countries.

Source: Prorok et al. (2017).

\section{Clusters for EU countries}

\begin{tabular}{|c|c|c|c|c|c|c|c|}
\hline $\mathrm{C} 1$ & $\mathrm{C} 2$ & $\mathrm{C} 3$ & $\mathrm{C} 4$ & & $\mathrm{C} 1$ & $\mathrm{C} 2$ & $\mathrm{C} 3$ \\
\hline $\begin{array}{l}\text { Austria, } \\
\text { Germany, } \\
\text { United } \\
\text { Kingdom, } \\
\text { Ireland }\end{array}$ & $\begin{array}{l}\text { France, } \\
\text { Italy, } \\
\text { Greece, } \\
\text { Portugal, } \\
\text { Spain, } \\
\text { Cyprus, } \\
\text { Malta, } \\
\text { Croatia }\end{array}$ & $\begin{array}{l}\text { Luxembourg, } \\
\text { Netherlands, } \\
\text { Denmark, } \\
\text { Finland, } \\
\text { Sweden }\end{array}$ & $\begin{array}{l}\text { Belgium, } \\
\text { Czech Republic, } \\
\text { Estonia, } \\
\text { Hungary, } \\
\text { Latvia, } \\
\text { Lithuania, } \\
\text { Poland, } \\
\text { Slovakia, } \\
\text { Slovenia, } \\
\text { Bulgaria, } \\
\text { Romania }\end{array}$ & & $\begin{array}{l}\text { Switzerland, } \\
\text { Norway, } \\
\text { Iceland }\end{array}$ & $\begin{array}{l}\text { Turkey, } \\
\text { Ukraine, } \\
\text { Russia }\end{array}$ & $\begin{array}{l}\text { Serbia, } \\
\text { Bosnia and } \\
\text { Herzegovina, } \\
\text { Macedonia, } \\
\text { Albania, } \\
\text { Montenegro, } \\
\text { Moldova, } \\
\text { Georgia, } \\
\text { Armenia }\end{array}$ \\
\hline PC1 & $\begin{array}{l}P C 2 \text { and } \\
P C 1\end{array}$ & PC2 & $\begin{array}{l}\text { Countries where } \\
\text { both defined } \\
\text { components } \\
\text { are negatively } \\
\text { profiled and do } \\
\text { not currently } \\
\text { contribute to } \\
\text { the tourism } \\
\text { competitiveness } \\
\text { of the countries. }\end{array}$ & $\begin{array}{l}\text { Similar to } \\
\text { the profile } \\
\text { defined by: }\end{array}$ & $P C 1$ and $P C 2$ & PC2 & $\begin{array}{l}\text { Countries where } \\
\text { both defined } \\
\text { components } \\
\text { are negatively } \\
\text { profiled and do } \\
\text { not currently } \\
\text { contribute to } \\
\text { the tourism } \\
\text { competitiveness } \\
\text { of the countries. }\end{array}$ \\
\hline PC2 & & PC1 & & $\begin{array}{l}\text { Unlike the } \\
\text { profile } \\
\text { defined by: }\end{array}$ & & PC1 & \\
\hline
\end{tabular}

\subsection{Output Variable Identification}

The development of tourism as an economic branch has a strong influence on both economic and non-economic aspects of development. The economic functions of tourism are reflected in its direct influence on: social product and national income, development of underdeveloped areas, balance of payments and employment; while its indirect influence is visible in the increased development of production of materials (industry, construction, agriculture) fueling the tourism industry. The non-economic or social aspects of tourism development relate primarily to the following functions: health, entertainment, cultural, social and political. The non-economic or social aspects of tourism development relate primarily to the following functions: health, entertainment, cultural, social and political. These functions stand out as crucial for the development of a country's tourism, and their neglect would undermine the practicality of treating tourism as a development option.
Given that this paper deals with the efficiency of tourism from an economic standpoint, our analysis focuses on economically measurable indicators of total (direct and indirect) contribution of travel and tourism to GDP and on the contribution of travel and tourism to employment. The two variables mentioned above will be used as output variables when evaluating tourism efficiency using the DEA method.

The World Travel and Tourism Council continually publishes data on total tourism contributions to GDP, which is methodologically consistent with the UNWTO (TSA RMF 2008) recommendation, and corresponds to GDP calculation in national accounts (Đuranović and Radunović, 2011).This aggregate is also an indicator of the shift of social products from economically developed to economically less developed countries. In this way, a more uniform development of the world's power is achieved.

In addition to its contribution to GDP, it is important to look at the impact of tourism on employment, i.e. opening of new jobs. The largest number of jobs is created in the hotel 
and restaurant sector, as well as in other supporting activities. It should also be emphasized that tourism has been opening jobs for staff of different degrees of expertise and education for years. This trend continues, with growing demand for highly flexible staff, possessing adequate competencies and capabilities to meet future tourism needs. Also, the World Economic Forum regularly publishes data on the contribution of tourism to total employment, reflecting the actual state of affairs.

\section{EVALUATION OF EFFICIENCY OF TOURISM IN EUROPEAN COUNTRIES}

The overall and pure technical efficiency of tourism in European countries was assessed by using the output-oriented CCR and BCC model. Two groups of countries were observed. The first group consists of $28 \mathrm{EU}$ member states, while the other group consists of 14 countries outside the European Union, including

Table 2a.

Evaluation of overall and pure technical efficiency of EU countries in 2017, using output-oriented CCR and BCC DEA models. Source: Authors' calculations.

\begin{tabular}{|c|c|c|c|c|}
\hline Country (DMU) & CCR efficiency score & Rank & BCC efficiency score & Rank \\
\hline Cyprus & 1 & 1 & 1 & 1 \\
\hline Malta & 1 & 1 & 1 & 1 \\
\hline Bulgaria & 1 & 1 & 1 & 1 \\
\hline Portugal & 0.9911 & 4 & 1 & 1 \\
\hline Croatia & 0.9225 & 5 & 1 & 1 \\
\hline Greece & 0.7269 & 6 & 1 & 1 \\
\hline Estonia & 0.6906 & 7 & 1 & 1 \\
\hline Ireland & 0.6901 & 8 & 1 & 1 \\
\hline Poland & 0.6761 & 9 & 1 & 1 \\
\hline Sweden & 0.6116 & 10 & 1 & 1 \\
\hline Spain & 0.5804 & 11 & 1 & 1 \\
\hline Romania & 0.5493 & 12 & 1 & 1 \\
\hline Slovenia & 0.5336 & 13 & 1 & 1 \\
\hline Netherlands & 0.507 & 14 & 1 & 1 \\
\hline Italy & 0.4797 & 15 & 1 & 1 \\
\hline Latvia & 0.4126 & 16 & 1 & 1 \\
\hline Czech Republic & 0.389 & 17 & 1 & 1 \\
\hline Finland & 0.3722 & 18 & 1 & 1 \\
\hline Hungary & 0.3587 & 19 & 1 & 1 \\
\hline Denmark & 0.3453 & 20 & 1 & 1 \\
\hline Slovakia & 0.3421 & 21 & 1 & 1 \\
\hline Luxembourg & 0.2756 & 22 & 1 & 1 \\
\hline Belgium & 0.2511 & 23 & 1 & 1 \\
\hline Lithuania & 0.2197 & 24 & 1 & 1 \\
\hline Austria & 0 & 25 & 0.0001 & 25 \\
\hline France & 0 & 25 & 0 & 26 \\
\hline Germany & 0 & 25 & 0 & 26 \\
\hline UK & 0 & 25 & 0 & 26 \\
\hline
\end{tabular}


the West Balkans. For both groups of countries, we determined two input and two output variables for efficiency evaluation. Input variables for both groups of countries were obtained on the basis of rating of 14 pillars defined in the annual report on tourist competitiveness of countries in 2017, and released by the World Economic Forum (WEF). We reduced the number of input variables by applying the principal component analysis (PCA) method. Thus, two input components were formed for both groups of countries, based on a linear combination of 14 defined pillars. Given that the linear combinations for the observed groups of countries were different, their efficiency had to be evaluated separately. The structure of the principal components was presented in the previous chapter. For output variables, data on the total contribution of travel and tourism to GDP, and data on the direct contribution of travel and tourism to the rate of employment growth, where both variables were expressed in percentages, were used. Data on output variables are from 2017 and were downloaded from the World Data Atlas site (https:// knoema.com/atlas).

Tables $2 a$ and $2 b$ illustrate the results of the overall and pure technical efficiency of EU countries and non-EU countries using the output-oriented CCR and BCC DEA models. Countries are ranked by their tourism efficiency. For analysis purposes, we used the DEA-Solver-LV software package.

The results for EU member states show that the following countries received the highest ratings for overall technical efficiency: Cyprus, Malta and Bulgaria. The efficiency coefficient value for the three mentioned countries is 1 , indicating that these countries have reached total technical efficiency within the observed set of countries and that they represent a reference set against which the relative efficiency of other countries is assessed. Slightly lower efficiency scores were realized by Portugal (0.9911) and Croatia (0.9225), followed by Greece (0.7269), Estonia (0.6906), Ireland (0.6901), etc. It should be noted that, judging from the defined output and input variables, countries such as Austria, France, Germany and the UK have proven to be completely inefficient compared to the reference units.

When it comes to non-EU countries, the most efficient units, with the efficiency coefficient of 1, were the following countries: Turkey, Albania, Montenegro, Georgia, Ukraine and Armenia; while relatively inefficient countries were: Moldova (0.8913), Macedonia (0.7826), Bosnia and Herzegovina (0.6115), Serbia (0.4268), etc.

From the Western Balkan countries, which according to defined input variables belong to cluster 3, Albania and Montenegro had the highest efficiency scores, while Macedonia, Bosnia and Herzegovina and Serbia achieved relatively poor overall technical efficiency scores.

It should be noted that same efficiency scores would be obtained with the input-oriented CCR model, with the orientation being different.

Table $2 \mathrm{~b}$.

Evaluation of overall and pure technical efficiency of non-EU countries in 2017, using output-oriented CCR and BCC DEA models. Source: Authors' calculations.

\begin{tabular}{lllll} 
Country (DMU) & CCR efficiency score & Rank & BCC efficiency score & Rank \\
\hline Turkey & 1 & 1 & 1 & 1 \\
\hline Albania & 1 & 1 & 1 & 1 \\
\hline Montenegro & 1 & 1 & 1 & 1 \\
\hline Georgia & 1 & 1 & 1 & 1 \\
\hline Ukraine & 1 & 1 & 1 & 1 \\
\hline Armenia & 1 & 1 & 1 & 1 \\
\hline Moldavia & 0.8913 & 7 & 1 & 1 \\
\hline Macedonia & 0.7826 & 8 & 1 & 1 \\
\hline Bosnia and Herzegovina & 0.6115 & 9 & 1 & 1 \\
\hline Serbia & 0.4268 & 10 & 1 & 1 \\
\hline Russia & 0.3057 & 11 & 0.9999 & 12 \\
\hline Iceland & 0.004 & 12 & 0.0001 & 13 \\
\hline Switzerland & 0 & 13 & 0 & 14 \\
\hline Norway & 0 & 13 & & 1 \\
\hline
\end{tabular}


The results of the assessment of pure technical efficiency of EU member countries show that most countries achieved full efficiency. Countries that did not achieve pure technical efficiency are France, Austria, Germany and Great Britain. The pure technical efficiency coefficient for these four countries is zero. However, given that the coefficient of their overall technical efficiency is zero, and that, according to a large number of tourism indicators (revenues from tourism, number of employees in tourism, etc.) they are ranked relatively high; we can conclude that these countries achieve tourism development through the efficiency of scale.

Likewise, almost all non-EU countries achieved pure technical efficiency, with only Switzerland and Norway having the coefficient of efficiency equal to zero. It should also be noted that all Western Balkan countries had the pure technical efficiency coefficient of 1 . Albania and Montenegro, in addition to achieving pure technical efficiency, also achieved the efficiency of scale, because their coefficient of overall technical efficiency is 1. Countries that had a lower coefficient of overall technical efficiency, with a high value of coefficient of pure technical efficiency, did not achieve efficiency in terms of scale. This is the case with countries such as Macedonia, Bosnia and Herzegovina, and Serbia. In other words, lower CCR coefficient value combined with high $B C C$ value, mean that these countries are locally but not globally efficient, which is again a consequence of inefficiency of scale. Inefficiency of scale may be the result of inefficient operational activities and / or conditions unfavorable for the development of tourism.

It is particularly interesting for purposes of this research to note the position of the Western Balkan countries in relation to other countries, primarily those that are not part of the EU. Using the principal component analysis method and then the cluster method, we grouped West Balkans countries into one cluster (C3) and showed that none of the two defined components currently contributes positively to the overall tourist competitiveness of these countries. This resulted in lower scores of total technical efficiency, and consequently, of efficiency of scale. Economic policy makers should interpret this as an indication of the need to draw up strategies and operational measures in the field of tourism.

The achievement of global efficiency requires a tourism development strategy for the entire region. The strategy should be based on innovative trends in tourism, for which there are enormous potentials in the Balkans.

\section{CONCLUSION AND DISCUSSION}

In this paper we evaluated the overall and pure technical efficiency of tourism in European countries using CCR and BCCDEA methods. We divided the countries into two groups: EU countries and non-EU countries. Two input and two output variables were identified for each group. Input variables were presented by linear combinations of 14 pillars on the basis of which The Travel and Tourism Competitiveness Index (TTCI) is formed. Countries were clustered on the basis of defined input variables, using the cluster method to form relatively homogeneous decisionmaking units that have similar or identical tourism potentials, from the point of view of natural resources, cultural and historical heritage, geographical location, infrastructure, etc. In that sense, cluster C3, to which Western Balkan countries belong, was distinguished as a special cluster within non-EU countries. The aforementioned cluster is characterized by negative profiles of both principal components. In addition, by defining output variables, we estimated the relative efficiency of all observed units. Analysis results facilitated the identification of advantages and disadvantages of post-transition countries in terms of their tourism competitiveness.

Among Western Balkan countries, Albania and Montenegro have been most effective in achieving full and pure technical efficiency compared to other observed units from the group of non-EU countries. Bosnia and Herzegovina, Serbia and Macedonia have achieved lower coefficient of total technical efficiency, while their coefficient of pure technical efficiency was one. These results indicate that the three mentioned post-transition countries are ineffective in terms of scale, possibly as a result of the non-existence or inefficient implementation of operational activities in the field of tourism, as well as of unfavorable conditions for its development. Therefore, if these countries are to improve their tourist competitiveness, they should pursue tourist offer based on relatively inexpensive and pre-existing resources that do not require significant investments. This can be achieved through the development of specialized tourism products based on innovative trends in tourism, for which Western Balkan countries have enormous potential. These forms of tourist offer could include various subtypes of health tourism, dark tourism, cultural tourism, educational tourism, etc. Such a tourism development strategy for the entire West Balkans region, would give these countries an opportunity to become globally recognizable and significantly improve their competitiveness. The presented findings of the research conducted indicate that the identification of the causes of the modest contribution of tourism to the GDPs of most non-EU countries of the West Balkans requires more detailed individual analysis.

\section{REFERENCES}

Andersen, P. \& Petersen, N.C., 1993. A Procedure for Ranking Efficient Units in Data Envelopment Analysis. Management Science, 39(10), pp.1261-1264. Available at: http://dx.doi.org/10.1287/mnsc.39.10.1261.

Assaf, A. \& Cvelbar, L.K., 2010. The performance of the Slovenian hotel industry: evaluation post-privatisation. International Journal of Tourism Research, pp.462471. Available at: http://dx.doi.org/10.1002/jtr.765. 
Baker, M. \& Riley, M., 1994. New perspectives on productivity in hotels: some advances and new directions. International Journal of Hospitality Management, 13(4), pp.297-311. Available at: http://dx.doi.org/10.1016/0278-4319(94)90068-x.

Banker, R.D. \& Morey, R.C., 1986. Efficiency Analysis for Exogenously Fixed Inputs and Outputs. Operations Research, 34(4), pp.513-521. Available at: http://dx.doi. org/10.1287/opre.34.4.513

Banker, R.D., Charnes, A. \& Cooper, W.W., 1984. Some Models for Estimating Technical and Scale Inefficiencies in Data Envelopment Analysis. Management Science, 30(9), pp.1078-1092. Available at: http://dx.doi.org/10.1287/mnsc.30.9.1078.

Barros, C.P. \& Alves, F.P., 2004. Productivity in the tourism industry. International Advances in Economic Research, 10(3), pp.215-225. Available at: http://dx.doi. org/10.1007/bf02296216.

Barros, C.P. \& José Mascarenhas, M., 2005. Technical and allocative efficiency in a chain of small hotels. International Journal of Hospitality Management, 24(3), pp.415-436. Available at: http://dx.doi.org/10.1016/j.ijhm.2004.08.007.

Barros, C.P. et al., 2011. Performance of French destinations: Tourism attraction perspectives. Tourism Management, 32(1), pp.141-146. Available at: http://dx.doi. org/10.1016/j.tourman.2010.01.015.

Bi, G., Luo, Y. \& Liang, L., 2011. Efficiency Evaluation of Tourism Industry With Data Envelopment Analysis (DEA): A Case Study in China. Journal of China Tourism Research, 7(1), pp.104-116. Available at: http://dx.doi.org/10.1080/19388160.2011 .551056 .

Botti, L., Peypoch, N., Robinot, E., Solonandrasana, B., 2009. Tourism destination competitiveness: the French regions case. European Journal of Tourims Reasearch, 21, pp.5-24.

Charnes, A., Cooper, W.W. \& Rhodes, E., 1979. Measuring the efficiency of decisionmaking units. European Journal of Operational Research, 3(4), p.339. Available at: http://dx.doi.org/10.1016/0377-2217(79)90229-7.

Charnes, A., Cooper, W.W. \& Rhodes, E., 1981. Evaluating Program and Managerial Efficiency: An Application of Data Envelopment Analysis to Program Follow Through. Management Science, 27(6), pp.668-697. Available at: http://dx.doi. org/10.1287/mnsc.27.6.668

Cracolici, M.F., Nijkamp, P. \& Rietveld, P., 2008. Assessment of Tourism Competitiveness by Analysing Destination Efficiency. Tourism Economics, 14(2), pp.325-342. Available at: http://dx.doi.org/10.5367/000000008784460427.

Cuccia, T., Guccio, C., Rizzo, I., 2013. Does UNESCO inscription affect the performance of tourism destinations? A regional perspective, ACEl working papers series, AWP04-2013.

Cvetkoska, V.and Barišić, P., 2014. Measuring the efficiency of certain European Countries in tourism: DEA window analysis. Book of Proceedings of the International May Conference on strategic management - IMKS14. Bor, University of Belgrade.

Davutyan, N., 2007. Measuring the quality of hospitality at Antalya. International Journal of Tourism Research, 9(1), pp.51-57. Available at: http://dx.doi.org/10.1002/ jtr.580.

Đuranović, M,. and Radunović, M., 2011. Analiza efekata turizma na BDP, zaposlenost i platni bilans Crne Gore. Sektor za istraživanje i statistiku. Centralna banka Crne Gore.

Hadad, S. et al., 2012. The Economic Efficiency of the Tourism Industry: A Global Comparison. Tourism Economics, 18(5), pp.931-940. Available at: http://dx.doi. org/10.5367/te.2012.0165.

Hwang, S.-N. \& Chang, T.-Y., 2003. Using data envelopment analysis to measure hotel managerial efficiency change in Taiwan. Tourism Management, 24(4), pp.357-369.
Available at: http://dx.doi.org/10.1016/s0261-5177(02)00112-7.

Jakšić-Stojanović, A., Šerić, N., 2018, The Montenegrin Lighhouses as Destination Icons, University Mediterranean Podgorica, Montenegro.

Jeremić, V.M., 2012. Statistički model efikasnosti zasnovan na Ivanovićevom odstojanju. Doktorska disertacija, Fakultet organizacionih nauka, Univerzitet u Beogradu, Beograd.

Johns, N., Howcroft, B. and Drake, L., 1997. The use of data envelopment analysis to monitor hotel productivity. Progress in Tourism Management, 3(2), pp.119-127. Available at: https://doi.org/10.1002/(sici)1099-1603(199706)3:2\%3C119::aidpth74\%3E3.3.co;2-u.

Kosmaczewska, J., 2014. Tourism interest and the efficiency of its utilization based on the example of the EU countries. Oeconomia, 13(1), pp.77-90.

Luo, Y., Qian, X., 2017. Efficiency Evaluation and Countermeasures of Inter-provincial Tourism in China. Revista de la Facultad de Ingenieria U.C.V., 32(5), pp.282-290.

Manasakis, C., Apostolakis, A. \& Datseris, G., 2013. Using data envelopment analysis to measure hotel efficiency in Crete. International Journal of Contemporary Hospitality Management, 25(4), pp.510-535. Available at: http://dx.doi. org/10.1108/09596111311322907.

Marcikić Horvat, A. and Radanov, B., 2016. Analiza efikasnosti razvoja turizma regiona primenom DEA metode. International Thematic Monograph - Thematic Proceedings: Modern Management Tools and Economy of Tourism in Present Era.

Martín, J.C., Mendoza, C. \& Román, C., 2015. A DEA Travel-Tourism Competitiveness Index. Social Indicators Research, 130(3), pp.937-957. Available at: http://dx.doi. org/10.1007/s11205-015-1211-3.

Meesters, A. J., 2009. Efficiency of financial institutions: a stochastic frontiel analysis approach. Groningen: University of Groningen.

Oukil, A., Channouf, N. \& Al-Zaidi, A., 2016. Performance evaluation of the hotel industry in an emerging tourism destination: The case of Oman. Journal of Hospitality and Tourism Management, 29, pp.60-68. Available at: http://dx.doi. org/10.1016/j.jhtm.2016.05.003

Pecina, M., 2006. Metode multivarijantne analize - osnove, Sveučilište u Zagrebu Agronomski fakultet.

Peypoch, N., 2007. On Measuring Tourism Productivity. Asia Pacific Journal of Tourism Research, 12(3), pp.237-244. Available at: http://dx.doi. org/10.1080/10941660701416812.

Phillips, P. \& Louvieris, P., 2005. Performance Measurement Systems in Tourism, Hospitality, and Leisure Small Medium-Sized Enterprises: A Balanced Scorecard Perspective. Journal of Travel Research, 44(2), pp.201-211. Available at: http:// dx.doi.org/10.1177/0047287505278992.

Prorok, V., Bošnjak, N., 2018. Measuring the technical efficiency of insurance companies in Bosnia and Herzegovina. Congress Proceedings, Mediterranean International Congress on Social Sciences, Mecas III, Budapest.

Prorok, V., Bošnjak, N., 2018. The analysis of the overall technical efficiency of insurance companies in Bosnia and Herzegovina.VI REDETE Conference, Banja Luka.

Prorok, V., Popović, B., Timotić, V., Balotić, G., 2017. Identification of Key Determinants for the Tourism Performance Improvement in the Western Balkan countries. Congress Proceedings, Mediterranean International Congress on Social Sciences, Mecas II, Ohrid.

Sanjeev, G.M.,2007.Measuring efficiency of the hotel and restaurant sector:the case of India V. Jauhari, ed. International Journal of Contemporary Hospitality Management, 19(5), pp.378-387. Available at: http://dx.doi.org/10.1108/09596110710757543. 
Savić, G., 2011. Matematički modeli efikasnosti - skripta. Fakultet organizacionih nauka, Beograd.

Šerić, N. \& Ljubica, J., 2018. Market Research Methods in the Sports Industry. Available at: http://dx.doi.org/10.1108/9781787541917.

Sigala, M., 2004. Using Data Envelopment Analysis for Measuring and Benchmarking Productivity in the Hotel Sector, Journal of Travel and Tourism Marketing, 16(2), pp.39-60. Available at: https://doi.org/10.1300/j073v16n02_04.
Soysal-Kurt, H., 2017. Measuring Tourism Efficiency of European Countries by Using Data Envelopment Analysis. European Scientific Journal, ESJ, 13(10), p.31. Available at: http://dx.doi.org/10.19044/esj.2017.v13n10p31.

Toma, E., 2014. Regional scale efficiency evaluation by input-oriented data envelopment analysis of tourism. International Journal of Academic Research in Environment and Geography, 1(1), pp.15-20. 